\title{
Publisher Correction: Profiling the susceptibility of Pseudomonas aeruginosa strains from acute and chronic infections to cell-wall- targeting immune proteins
}

Gabriel Torrens, Isabel M. Barceló, Marcelo Pérez-Gallego, Maria Escobar-Salom, Sara TurGracia, Marta Munar-Bestard, María del Mar González-Nicolau, Yoandy José CabreraVenegas, Estefany Nayarith Rigo-Rumbos, Gabriel Cabot, Carla López-Causapé, Estrella Rojo-Molinero, Antonio Oliver \& Carlos Juan (D)

Correction to: Scientific Reports https://doi.org/10.1038/s41598-019-40440-w, published online 05 March 2019

A Supplementary File containing Figures S1, S2, S3, S4 and S5 was omitted from the original version of this Article. This has been corrected in the HTML version of the Article; the PDF version was correct at time of publication.

(c) (1) Open Access This article is licensed under a Creative Commons Attribution 4.0 International c. License, which permits use, sharing, adaptation, distribution and reproduction in any medium or format, as long as you give appropriate credit to the original author(s) and the source, provide a link to the Creative Commons license, and indicate if changes were made. The images or other third party material in this article are included in the article's Creative Commons license, unless indicated otherwise in a credit line to the material. If material is not included in the article's Creative Commons license and your intended use is not permitted by statutory regulation or exceeds the permitted use, you will need to obtain permission directly from the copyright holder. To view a copy of this license, visit http://creativecommons.org/licenses/by/4.0/.

(C) The Author(s) 2020 